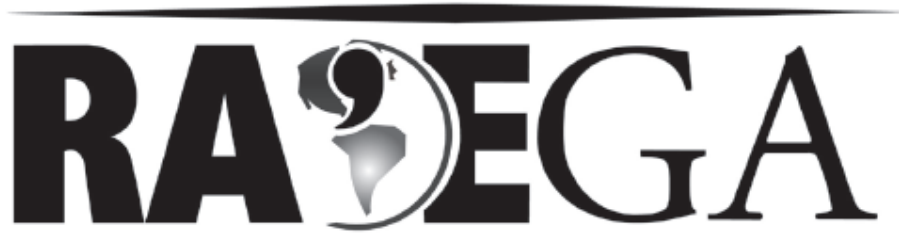

O ESPAÇO GEOGRÁFICO EM ANÁLISE

\title{
A ÁGUA COMO SUPORTE PARA ATIVIDADES DE LAZER E TURISMO: POSSIBILIDADES E LIMITAÇÕES DA BARRAGEM PIRACURUCA NO ESTADO DO PIAUÍ (BRASIL)
}

\section{WATER AS A SUPPORT FOR TOURISM AND LEISURE ACTIVITIES: POSSIBILITIES AND LIMITATIONS OF THE STATE OF DAM PIRACURUCA PIAUII (BRAZIL)}

\author{
Roberta Celestino Ferreira ${ }^{1}$ \\ Wilza Gomes Reis Lopes ${ }^{2}$ \\ José Luis Lopes Araújo ${ }^{3}$
}

\section{RESUMO}

Na década de 1970 houve uma piora na qualidade da preservação ambiental, devido ao crescimento econômico e populacional e, consequentemente, na vida da sociedade dos grandes centros urbanos. Com isso, a ideia de que os recursos naturais não são infinitos gerou os primeiros esboços do conceito de desenvolvimento sustentável. Nesse sentido, se o turismo for bem planejado, haverá condições de ocorrer inovações dentro de um plano de desenvolvimento do local. Dessa maneira, o presente trabalho tem como objetivo verificar as possibilidades e limitações, levantar os impactos positivos e

\footnotetext{
1 Turismóloga, Mestre em Desenvolvimento e Meio Ambiente pelo Programa de Pós-Graduação em Desenvolvimento e Meio Ambiente (PRODEMA) da Universidade Federal do Piauí (UFPI), Teresina, Piauí, Brasil (robertacelestino_the@hotmail.com).

2 Arquiteta, Professora Associada do Departamento de Construção Civil e Arquitetura e do Programa de Pós-Graduação em Desenvolvimento e Meio Ambiente (PRODEMA) da Universidade Federal do Piauí (UFPI), Teresina, Piauí, Brasil (izalopes@uol.com.br).

Geógrafo, Professor do Departamento de Geografia e do Programa de Pós-Graduação em Desenvolvimento e Meio Ambiente (PRODEMA) da Universidade Federal do Piauí (UFPI), Teresina, Piauí, Brasil (jlopesaraujo@gmail.com).
} 
negativos, assim como, identificar as formas de lazer e turismo desenvolvidas na Barragem Piracuruca, localizada no município de Piracuruca, Estado do Piauí. Para isso será discutida a relação entre a atividade turística e o meio natural, sendo que, dentro desta relação, será aplicado o conceito de desenvolvimento sustentável. Foram realizadas pesquisas bibliográficas em livros e artigos, voltados para turismo e paisagem, aproveitamento das águas para lazer e turismo, e, ainda, em leis e documentos de instituições ligadas ao uso e gestão dos recursos hídricos no Brasil. Também foi realizada pesquisa de campo, com o objetivo de registrar, fotograficamente a movimentação de visitantes na referida barragem. Para identificar as formas de turismo praticadas na barragem, baseou-se na observação direta, sendo relacionada à literatura conceitual sobre segmentação do turismo (BRASIL, 2006a). Com relação aos impactos positivos e negativos da atividade turística desenvolvida, também foi realizada observação direta, utilizando-se 0 Guia de Desenvolvimento do Turismo Sustentável (OMT, 2003) para respaldar os resultados encontrados. Concluiu-se que as possibilidades de desenvolvimento de atividades de lazer e do turismo em contato com o meio natural na barragem são muitas, destacando-se banho aquático e de sol, pesca, mirante, campeonato de jetski e show acústico. Outras atividades também podem ser executadas, desde que haja uma logística de estruturação e de infraestrutura, mostrando-se favorável ao desenvolvimento do ecoturismo, turismo de esportes, turismo de pesca, turismo náutico, turismo de aventura, turismo de sol e praia. Mas, a barragem sofre constantemente com o problema do lixo e despejo indevido de esgoto em suas águas, o que favorece os riscos à saúde da população e dos visitantes. Além disso, notou-se que a população piracuruquense mais carente está vivenciando um processo de "marginalização territorial", onde as casas mais pobres estão sendo afastadas da barragem e substituídas por construções mais luxuosas, o que demonstrou uma grande especulação imobiliária em toda a extensão da construção, o que não deixa de ser limitações ao desenvolvimento do turismo. A Barragem Piracuruca, tendo como atrativo suas belezas naturais, dispõe de boas condições para desenvolver o turismo, o que deve ser feito com prudência e diligência por parte da administração pública e pelos próprios visitantes.

Palavras-chave: Lazer; Turismo; Desenvolvimento Sustentável; Barragem Piracuruca.

\section{ABSTRACT}

In decade of 1970, environmental preservation became worse, due to economic and population growth, as well as life quality of society in big urban centers. Thus, comprehension of natural resources are limited have produced first drafts of sustainable development concept. Upon this perspective, if tourism is wellplanned, there will be conditions for innovation on a local development plan. This study has the objective to verify possibilities and limitations, to point out positive and negative impacts, as well as to identify leisure and tourism ways developed on Piracuruca Dam, located in Piracuruca county, Piauí state. Relation between touristic activity and environment was discussed and sustainable development was applied. It was realized bibliographic research on 
books and periodicals, related to tourism and landscape, water utilization for leisure and tourism, as well as laws and institutional documents for use and management of hydric resources in Brazil. A field research was also realized, with the objective of registering visitors' movement in dam by photos. In order to identify tourism ways practiced in dam, direct observation was effected, related to tourism segmentation (BRASIL, 2006a). As for positive and negative impacts of touristic activity developed, direct observation was also realized, by using Guide for Development of Sustainable Tourism (OMT, 2003) to give support to found results. The conclusion is that there are several possibilities for leisure and touristic activities' development in contact with environment, detaching water and sun bath, fishery, contemplation in belvedere, jetski championship and acoustic music shows. Other activities can also be executed, since logistic and infrastructure can be improved, being favorable to ecological tourism, sportive tourism, fishing tourism, nautical tourism, adventure tourism, sun and beach tourism. However, Piracuruca Dam is affected constantly with garbage problem and inadequate slop of sewer on water, causing risks to population and visitors' health. Besides, a "territorial marginalization" process of needy people, in which poorest homes have been removed from dam area and substituted by sumptuous constructions, which demonstrate a significant immovable speculation all over dam area, that impose limits to tourism development. Piracuruca Dam has the attractive of natural beauty and good conditions for tourism development, which must be done with prudence and diligence by public administration and visitors.

Keywords: Leisure; Tourism; Sustainable Development; Piracuruca Dam.

\section{Introdução}

Toda atividade antrópica gera consequências para o meio ambiente, que na maioria dos casos, são negativas para a natureza. No decorrer do tempo, contudo, tem-se buscado cada vez mais a conciliação entre as atividades humanas e o ecossistema, a fim de mitigar esses impactos danosos.

Com o advento das atividades industriais a partir da década de 1950, houve um aumento do consumo dos recursos naturais por causa da modernização dos meios produtivos, da explosão da demografia, do acelerado aumento dos centros urbanos e do processo de globalização. O modelo econômico, dessa forma, acelerou a demanda por produtos industriais. Tanto que, na visão de Seabra (2009, p. 12), "a voracidade do consumo humano 
rompeu com os critérios e mecanismos naturais para a preservação das espécies, decorrentes da seleção natural e evolução dos seres".

O turismo, associado à melhor qualidade de vida, tem se destacado como uma das atividades que mais tem crescido nos últimos anos. Visto que, o meio ambiente é o sustentáculo da atividade turística, as ações de planejamento devem estar voltadas para a prática do turismo sustentável, considerando-se que esta seria a melhor opção de preservação, evitando o processo de destruição do mesmo, pois "ao mesmo tempo em que a atividade turística simboliza o uso e a apropriação [...] também simboliza o empreendedorismo, a conquista, a descoberta, e o sonho de muitas pessoas" (CORIOLANO; VASCONCELOS, 2008, p.13).

O conceito de sustentabilidade aplicado ao turismo surgiu da necessidade de refletir sobre os impactos ocasionados ao meio ambiente. De acordo com Dias (2005), o turismo sustentável pode ser conceituado como a atividade que visa atender aos anseios dos visitantes, ao passo em que planeja suas ações pensando no futuro. A sustentabilidade do turismo é, assim, a harmonia entre a economia, a sociedade e o meio ambiente.

Dessa forma, a atividade turística necessita de planejamento, para que seja possível a sua efetiva consolidação, em regiões que apresentem potencial para a implantação de atividades de lazer. Segundo Diegues (2000), se a atividade turística for bem planejada, haverá condições de ocorrer inovações em um plano de desenvolvimento sustentável do lugar, possibilitando o crescimento socioeconômico não só para o local, mas para diversas regiões.

Entretanto, para que o turismo seja viável socioeconomicamente, essa atividade deve ser implantada dentro de parâmetros sustentáveis, ou seja, "o núcleo receptor, a região, o Estado devem definir uma política de estratégias e ações para o turismo, promovendo a conservação socioambiental, contemplando os aspectos econômicos e culturais" (QUEIROZ, 2009, p. 175). O turismo, se desenvolvido com os critérios básicos de desenvolvimento sustentável, pode promover a preservação do meio ambiente, além de conferir o crescimento econômico e uma atividade que minimize impactos decorrentes de sua atividade. 
O presente trabalho teve como objetivo verificar as possibilidades e limitações, levantar os impactos positivos e negativos, assim como, identificar as formas de lazer e turismo desenvolvidas na Barragem Piracuruca, localizada no município de Piracuruca, Estado do Piauí.

Para elaboração do trabalho, foram realizadas pesquisas bibliográficas em livros e artigos voltados para turismo e paisagem, aproveitamento das águas para lazer e turismo e, ainda, em leis e documentos de instituições ligadas ao uso e gestão dos recursos hídricos no Brasil, como a Agência Nacional das Águas (ANA), e o Conselho Nacional de Recursos Hídricos (CNRH). Também foi realizada pesquisa de campo, com o objetivo de registrar fotograficamente a movimentação de visitantes na referida barragem.

Para identificar as formas de turismo praticadas na barragem, baseou-se na observação direta, sendo relacionada à literatura conceitual sobre segmentação do turismo (BRASIL, 2006a). Com relação aos impactos positivos e negativos da atividade turística desenvolvida, também foi realizada observação direta, utilizando-se o Guia de Desenvolvimento do Turismo Sustentável (OMT, 2003) para respaldar os resultados encontrados.

\section{Aproveitamento das águas para lazer e turismo}

As definições acerca de turismo são bastante controversas, pois estas, além de agregar valores a lugares e não-lugares turísticos, transforma-os à medida que se torna necessário, ou mesmo quando se cria um novo valor ao produto.

A paisagem é base da atividade turística, explorada como atrativo para os visitantes em determinada localidade. O impacto visual do ambiente a ser visitado pelo turista deve sempre ser positivo; nesse sentido, e com o intuito de se primar pela sustentabilidade (ambiental, sociocultural e econômica) do turismo, a paisagem (meio ambiente) sempre deve ser preservada, a fim de manter o turismo. 
É necessário entender que a interação entre turismo e meio ambiente é muito importante, pois a própria atividade do turismo precisa, logicamente, de um ambiente para acontecer, e esse ambiente tende a se descaracterizar pela ação antrópica. Quando qualquer atividade relacionada ao turismo é implementada, a natureza sofre com modificações, por conta da própria produção do turismo (COOPER; FLETCHER; FYALL, 2007).

A discussão sobre a paisagem possibilita considerar que um espaço de lazer pode ser construído em diversos locais, desde que eles atendam aos requisitos dos visitantes e do meio natural, tendo o turismo o poder de criar e recriar paisagens, de acordo com interesses econômicos. Para Coriolano e Vasconcelos (2007, p. 9),

o homem apropria-se da natureza transformando-a em espaço geográfico com a sua presença e suas interferências. A primeira natureza é modificada em segunda natureza com o espaço sendo produzido. A espacialidade deste processo define o surgimento de cidades, lugares, paisagens, territórios e ambientes para a realização do turismo, entre outras necessidades humanas. A base dessa relação está no trabalho. Os grupos econômicos, através de empresas e firmas, definem a produção, circulação, distribuição e consumo do turismo. São os interesses capitalistas que determinam o uso (consumo) do espaço e a relação social de produção do turismo. Portanto, mais do que uma simples relação do homem com a natureza, há uma relação sociedade e natureza. É a sociedade que determina as formas de uso da natureza ou mais precisamente do espaço, do trabalho e da riqueza. Assim, ocorre a espacialidade para e pelo turismo, juntamente com inúmeras atividades econômicas de apoio, tais como: os meios de transporte, de hospedagem, de agenciamentos, de lazeres e entretenimentos, além de outras ações mercadológicas.

Uma das formas de lazer e uso do tempo livre que mais tem se desenvolvido nas ultimas décadas é o turismo. Com raras exceções, o turismo praticado no meio natural tem se apropriado e provocado a modificação de ecossistemas naturais.

Um dos principais atrativos para turistas que buscam diversão e descanso são reservas de águas, sejam elas naturais ou artificiais. Como exemplo, pode-se citar as praias, lagoas, rios, barragens, balneários, cachoeiras, entre outros. 
A gestão racional da água é uma ação necessária para que a população mundial tenha uma vida agradável (ONU, 1992). Enfatiza-se, portanto, que além de ter valor econômico, a água que cuidamos agora será uma herança para as gerações posteriores, ditando o modo de vida dessa população no futuro.

Dentro dessa temática, a atividade turística deve apresentar especial atenção no aproveitamento das águas, sendo que sua gestão consciente é muito importante, pois na maioria dos casos, as mesmas águas aproveitadas para lazer servem para o abastecimento das populações locais, seja para consumo diário ou não. Assim, o compromisso com a preservação de tais fontes aquíferas cabe não somente aos gestores públicos e à sociedade autóctone, mas também aos visitantes.

O aproveitamento das águas para lazer e turismo relaciona-se, primeiramente, com a capacidade de suporte que o lugar tem para receber os turistas (infraestrutura, instruções de segurança, entre outros). Contudo, segundo Muller (2002), esses espaços e equipamentos destinados ao lazer têm sofrido desvalorização, pois não são entendidos como essenciais, não tendo atenção necessária por parte das políticas públicas. Dessa forma, em alguns locais de desenvolvimento do turismo em águas, observa-se a apatia e o conformismo de diversos segmentos da população, que não contribuem efetivamente para a devida manutenção dos equipamentos. Como por exemplo, é o caso da Praia Fluvial da Pedra Branca no Reservatório de Promissão no Estado de São Paulo (POLO, 2008).

Nessa perspectiva, Bruhns (2007, p. 89) afirma que “[...] devemos reavaliar as posturas interpretativas que contrapõem meio ambiente natural e artificial ou natureza e cultura de forma estanque e desvinculada, bem como as novas relações estabelecidas com esses ambientes, os quais se interpenetram numa ressignificação da própria natureza".

Então, a preservação de práticas de lazer em águas é alcançável por meio de uma reavaliação de como a sociedade, seja ela local ou visitante, está interagindo com o ambiente, pois tal reavaliação e mudança na postura 
ecológica como um todo, só traz benefícios à prática de um turismo sustentável.

O Brasil possui vastas possibilidades de turismo, por dispor de imensa quantidade de atrativos turísticos, tanto culturais quanto naturais. As atividades turísticas em todo o território nacional podem gerar empregos, além de incluir socialmente uma parcela da população considerada marginal.

Nesse caso, o turismo pode mitigar problemas sérios, como a desigualdade social, pois alguns dos destinos turísticos mais visitados do Brasil encontram-se em regiões carentes, que por causa do turismo acabam por ser visitadas por cidadãos mais ricos (BRASIL, 2005).

Os recursos hídricos brasileiros despertam interesse pelo seu grande potencial, sendo o país um dos que detém maior quantidade de água doce no mundo, dividida em doze grandes regiões hidrográficas, de acordo com o Conselho Nacional de Recursos Hídricos (CNRH), apresentado na figura 1.

Figura 1: Regiões hidrográficas do Brasil.

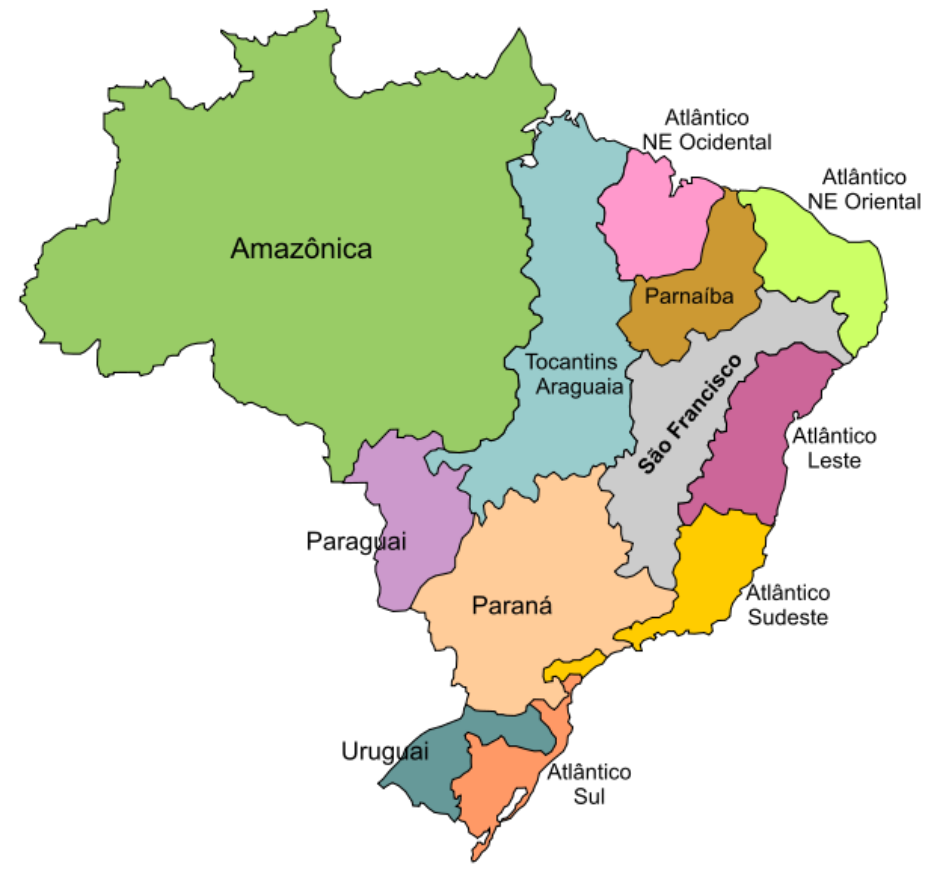

Fonte: BRASIL (2005)

Contudo, para gerir tamanha riqueza aquífera, foram elaboradas leis de uso e gestão da água em território nacional. $\mathrm{O}$ marco legal direcionado às 
fontes de água foi a lei oㅜ 9.433, de 8 de janeiro de 1997, a qual dispõe sobre a Política Nacional de Recursos Hídricos, criando assim o Sistema Nacional de Gerenciamento de Recursos Hídricos. A referida lei também regulamenta 0 inciso XIX do art. 21 da Constituição Federal, e altera o art. 1ํ da lei ํo 8.001, de 13 de março de 1990, que modificou a lei no 7.990, de 28 de dezembro de 1989 (BRASIL, 2005).

Assim, como forma de contribuir para a gestão dos recursos hídricos brasileiros, a ANA elaborou, em 2005, um trabalho intitulado "O turismo e o lazer e sua interface com o setor de recursos hídricos". Nesse documento, são identificados os principais segmentos do setor do turismo associado aos recursos hídricos, que são: turismo desenvolvido em toda a extensão do litoral brasileiro; turismo ecológico e pesqueiro e; turismo e lazer em lagos e reservatórios interiores, como barragens, por exemplo.

Sobre a atividade turística desenvolvida no litoral brasileiro, Brasil (2005) afirma que esse segmento sofre com perceptíveis problemas estruturais, principalmente na falta ou baixa eficiência do esgotamento sanitário, com decorrente comprometimento da balneabilidade das praias. Já sobre o turismo ecológico e o pesqueiro, esse tipo de atividade vem, no decorrer dos anos, transformando-se em uma das principais opções de exploração econômica de uma região.

Contudo, as áreas de lazer localizadas em reservatórios e lagos enfrentam sérios problemas, pois

[...] a poluição hídrica de represas, rios, lagos e cachoeiras representa um dos mais impactantes danos causados pelo crescimento descontrolado de atividades de turismo e recreação, devido ao lançamento de esgotos e à geração de resíduos em embarcações de recreio, que expelem gases, óleos e graxas, determinada pela ineficiência ou falta de coleta de lixo e pela falta de orientação dos próprios usuários (BRASIL, 2005, p. 19-20).

Observa-se que a legislação brasileira deixa claro que a água é um dos principais recursos da natureza, sendo que, sem o seu uso racional, é impossível desenvolver satisfatoriamente a humanidade e as atividades 
econômicas voltadas ao lazer. Dessa forma, é importante que as leis e sanções previstas sejam aplicadas rigorosamente, nos casos que sejam identificados abusos na utilização de fontes aquíferas públicas.

São muitos os reservatórios de água caracterizados para 0 aproveitamento da atividade turística no Brasil, tendo como critério principal sua beleza paisagística e a qualidade da água, tais como: Serra da Mesa (Goiás); Lajeado (Tocantins); Tucuruí (Pará); Três Marias (Minas Gerais); Sobradinho (Bahia); Xingó (situada na divisa entre Alagoas e Sergipe); Furnas (envolvendo Estados de Minas Gerais e São Paulo); Itaipu (Paraná); Caconde (São Paulo); Promissão (São Paulo) e Paranoá (Distrito Federal).

O segmento turístico que mais se destaca com relação ao uso de recursos hídricos, como forma de desenvolvimento, é o turismo de lazer de sol e praia, destacando-se os destinos turísticos já consolidados, tais como: Natal (Rio Grande do Norte), Porto Seguro (Bahia); Recife (Pernambuco); Florianópolis (Santa Catarina); entre outros.

Diverso e repleto de beleza cênica, os destinos turísticos respaldados tanto em atrativos culturais, como ambientais, sofrem nas férias de verão com a superlotação, pois a infraestrutura básica não comporta o aumento excessivo de habitantes e visitantes, ocasionando na incapacidade de tratamento das águas residuárias, reduzindo a qualidade das águas, podendo comprometer a atividade turística.

No Piauí, a busca por lazer e turismo em recursos hídricos é grande, podendo ser observado o grande movimento de visitantes rumo ao litoral piauiense. Mas as lagoas, barragens, cachoeiras, açudes e rios também são muito frequentados, o ano todo, tendo como exemplo: a Cachoeira do Urubu em Esperantina/Batalha, o açude Caldeirão em Piripiri, o balneário Corredores em Campo Maior, a barragem do Bezerro em José de Freitas, o balneário Curva São Paulo em Teresina, balneário Natal em monsenhor Gil, os Poços Jorrantes de Cristino Castro, a imensa lagoa de Parnaguá, o balneário Mesa de Pedra em Valença, entre outros, assim como a Barragem Piracuruca. 


\section{A Barragem Piracuruca e seu entorno}

O potencial para atividades de lazer existente em açudes e barragens faz com que esses locais representem uma opção para o desenvolvimento turístico regional. Segundo Barreto (2005, p. 83), "dependendo do estado de limpeza da água, da periculosidade das correntes, profundidade ou da situação geográfica, os lagos e as represas podem ser usados para a prática da pesca ou de esportes náuticos".

A bacia do rio Parnaíba possuía 19 barragens, com capacidade acima de $10.000 .000 \mathrm{~m}^{3}$ (BRASIL, 2006b), sendo que destas, nove eram administradas pela Companhia de Desenvolvimento do Piauí (COMDEPI): Algodões I com 59.100.000 m³; Piracuruca com 250.000.000 m³; Corredores de 63.300.000 m³; Bezerro com 11.000.000 m³; Mesa de Pedra com 55.700.000 m³ Salinas de 385.000.000 m³; Pedra Redonda com 216.000.000 m³; Poços de 43.000.000 $\mathrm{m}^{3}$ e Algodões II com 247.000.000 $\mathrm{m}^{3}$. Sete delas eram administradas pelo Departamento Nacional de Obras Contra as Secas (DNOCS): Petrônio Portela com 181.200.000 m³; Jenipapo com 248.000.000 m³; Ingazeiras com 25.700.000 m³; Estreito com $19.300 .000 \mathrm{~m}^{3}$; Barreiras com $52.800 .000 \mathrm{~m}^{3}$; Cajazeiras com 24.700.000 m³ e Caldeirão com $54.000 .000 \mathrm{~m}^{3}$. A AGESPISA (Águas e Esgotos do Piauí S/A) é responsável pela Barragem Salgadinha de 25.000.000 m; enquanto que, a Companhia de Gestão dos Recursos Hídricos (COGERH) gerencia a Barragem Carnaúbal, de 87.700.000 $\mathrm{m}^{3}$ e a Companhia Hidroelétrica do São Francisco (CHESF) administra a Barragem Boa Esperança, de 5.000.000.000 m³.

Entre as barragens localizadas no território piauiense, a Barragem Piracuruca é o terceiro maior reservatório de água do Estado, menor apenas que Boa Esperança e Salinas, atraindo muitos turistas durante todo o ano. Esse local gera oportunidades de emprego e renda à população, mesmo não sendo o turismo o principal objetivo da construção da barragem.

A região onde foi construída a barragem tem como principal característica a pouca profundidade do solo. A formação tectônica é preenchida 
por rochas formadas por sedimentação, começando seu processo de consolidação na Era Siluriana (PIAUÍ, 1987).

O clima do local é classificado como Aw', quente e úmido, com chuvas que ocorrem de verão a outono, com um inverno muito seco. Assim, na região da Barragem Piracuruca, a média pluviométrica é de $1.378 \mathrm{~mm}$ anuais, sendo que o maior nível de precipitação ocorre de janeiro a agosto. Entre agosto a outubro, pela falta de chuva, há um clima seco. Isso faz com que a temperatura de todo o município de Piracuruca fique em torno de $27,7^{\circ} \mathrm{C}$, não tendo muitas variações durante o ano (PIAUÍ, 1987).

Geomorfologicamente, a área da barragem tem drenagem dentrítica aberta, sendo composta por interflúvios escalonados e planos. Onde há planícies fluviais (na extensão do rio Piracuruca), o padrão geomorfológico é estreito e pouco significativo. Sobre a área do reservatório, localiza-se na porção oeste da Bacia do Meio-Norte, ou Bacia do Parnaíba. Essa bacia tem como principal característica seu tamanho. E por estar em uma rasa depressão tectônica, em sua extensão norte-sul ela comporta rochas de origem sedimentar.

Segundo Silva Filho (2002), na vegetação da região, há predominância do tipo Campo Cerrado, identificando-se, ainda, em menor escala as Florestas Subcaducifólias, situadas em áreas de maior fertilidade. Em outras áreas de solo raso são observadas espécies de Caatinga Arbustiva, e próximo aos cursos d'água há representantes de Floresta Ciliar de Carnaúba (Copernicia prunifera). No entorno da barragem a vegetação é bastante densa (Figura 2).

A fauna terrestre não é tão abundante, destacando-se: Vulpes vulpes (raposa); Euphractus sexcintus (peba); Cavea aperea (preá); Cyclopes didactylus (mambira); Crotalus terrificus (cascavel) Procyon cancrivorous (guaxinim); Dasypus novencinctus (tatu); Panthera pardalis (maracajá); Mazama americana (veado); Panthera uncia (onça). Já a fauna alada é mais abundante, tais como: Uropelia campestris (rolinha); Tinamus sp. (nambu); Zenaida auriculata (avoante); Leptotila rufaxilla (juriti); Crotophaga ani (anum preto); serinus canarius (canário); Columba picaruzo (asa branca); Volatunia jacarina (chico preto); Penelope superciliaris (jacu); Pitangus sulphuratus (bem- 
te-vi). A fauna aquática é composta pelas espécies: Hoplias malabaricus (traíra); Sorubim sp. (surubim); Prochilodus vimboides (curimatá); Leporinus sp. (piau); Ageneiosus brevifilis (mandi); Pygocentrus nattereri (piranha); Pseudoplatystoma curruscans (pintado); Trachycorystes striatulus (cangati); Mylossoma duriventre (pacu); Anodus spp (branquinha) (PIAUÍ, 1987, p. 38$39)$.

Figura 2: Vegetação no entorno da Barragem.

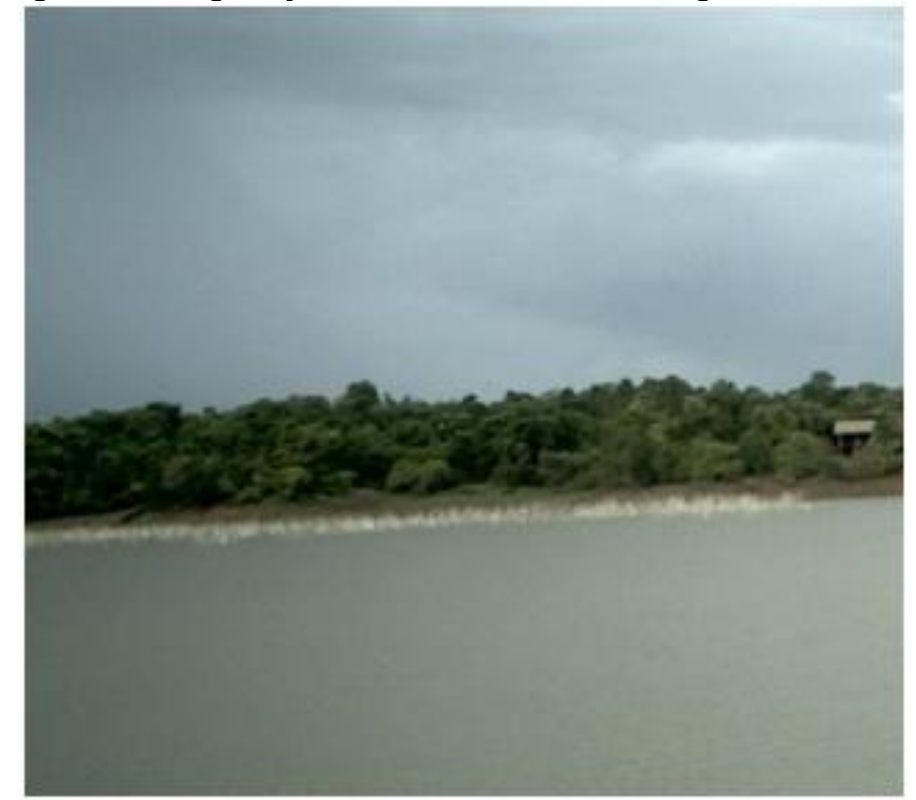

Fonte: Roberta Ferreira (2010)

Em janeiro de 1987, o Governo do Estado do Piauí, por meio da Secretaria Estadual de Planejamento (SEPLAN) e da Fundação Centro de Pesquisas Econômicas e Sociais do Piauí (FUNDAÇÃO CEPRO), contratou a empresa de Serviços Integrados de Assessoria e Consultoria (SIRAC), para realizar o Estudo de Impacto Ambiental (EIA) e o Relatório de Impacto Ambiental (RIMA), visando à construção da Barragem Piracuruca. No RIMA encontra-se exposto que a "implantação da Barragem Piracuruca e a subsequente formação do lago, principalmente por sua pouca expressiva lâmina d'água, tem impactos praticamente desprezíveis sobre a geologia da área" (PIAUÍ, 1987, p. 100). Mas o relatório, também, enfatizou que os impactos sobre a flora são inevitáveis; contudo, encontram considerável amortecimento e gradual reequilíbrio, por meio de medidas propostas pelo próprio estudo. 
Construída com recursos do Governo Federal, posteriormente passou para o controle do Governo do Estado, através da extinta Companhia de Desenvolvimento do Piauí (COMDEPI), absorvida pela Empresa de Gestão de Recursos do Piauí (EMGERPI). A obra foi concluída em dezembro de 1997 (PIAUÍ, 1997), mas inaugurada antes de sua conclusão, em 08 de maio de 1996 (MACHADO, 2008).

A barragem foi edificada no rio Piracuruca (Figura 3), principal curso d'água municipal, que nasce na Serra da Ibiapaba, a uma altitude em torno de 650 metros. Sua nascente fica compreendida entre o Serrote do Angical e a Serra dos Borges. No Estado do Ceará, o rio tem o nome de Arabé e sua foz está localizada na Barra do Piracuruca, onde alimenta o rio Longá. $O$ rio Piracuruca, em toda a sua extensão, atravessa os municípios de São Benedito (no Ceará), Domingos Mourão, São João da Fronteira, Brasileira, Piracuruca e São José do Divino, na região norte do Piauí (MACHADO, 2008).

Figura 3: Mapa de localização da Barragem Piracuruca.

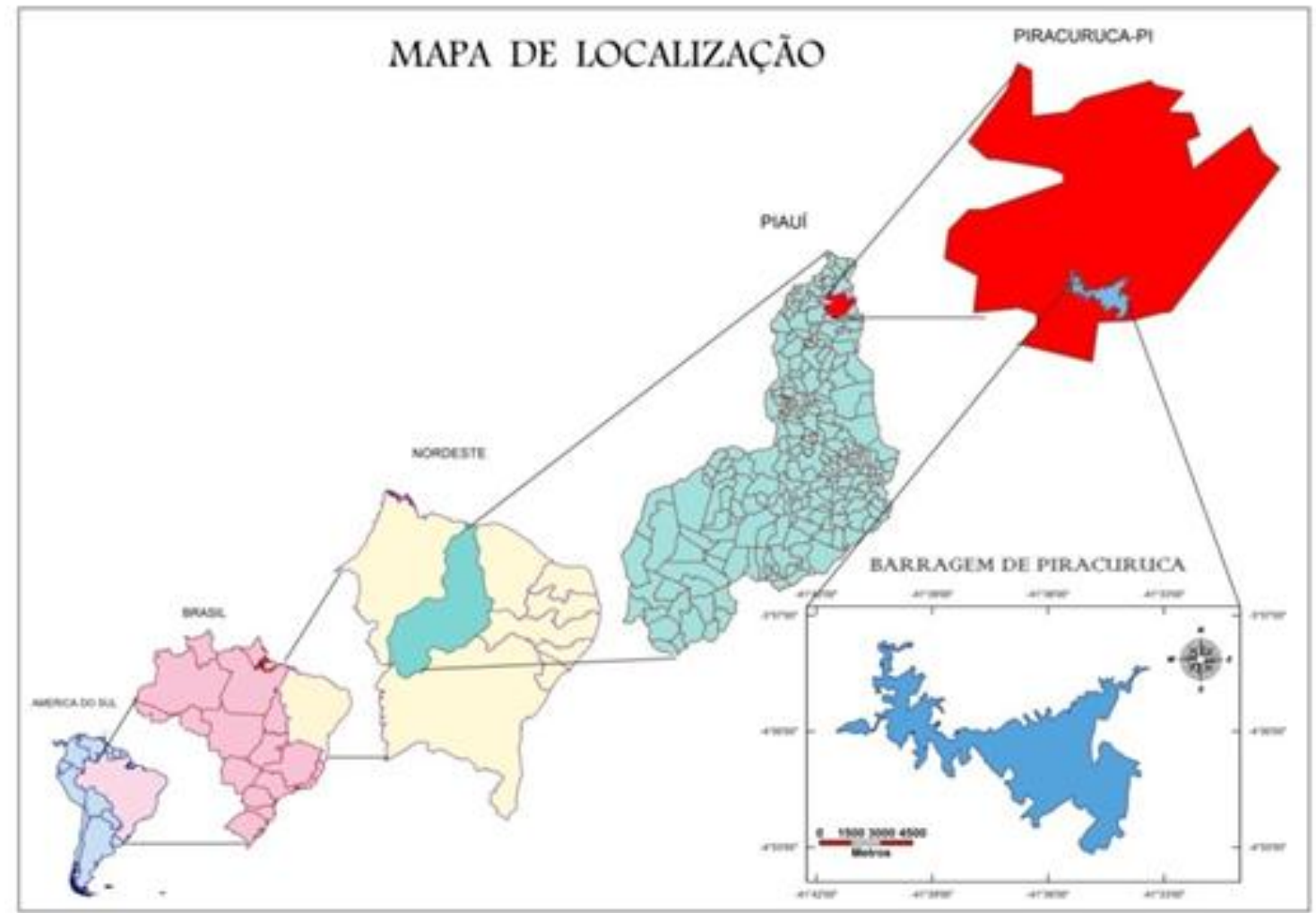

Fonte: IBGE adaptado por Kenard da Silva Costa (2010). 
A capacidade para armazenamento da barragem é de $250.000 .000 \mathrm{~m}^{3}$ de água, cobrindo uma área de aproximadamente 5.000 hectares, a Barragem Piracuruca é considerada como o maior reservatório do município, e o terceiro maior do Estado do Piauí. É utilizada para o abastecimento de água, de pesca, e usada como forma de lazer pela população local e por visitantes. Dispõe, ainda, de belezas naturais, como: recantos, ilhas, ninhais e mirante, demonstrando assim, seu potencial turístico em construção, com observância da prudência e diligência dos administradores públicos e seus usuários.

Com a construção da barragem, o Governo do Estado do Piauí, por meio da Companhia de Desenvolvimento do Piauí (COMDEPI), contratou a Consultoria e Planejamento (CONSPLAN) para realizar o Estudo de Impacto Ambiental (EIA) e o Relatório de Impacto Ambienta (RIMA) do projeto de irrigação da Barragem Piracuruca. O mesmo permitiu avaliar, com rigor, as alterações provocadas em decorrência do projeto, no meio terrestre (solos, vegetação, fauna e relevo), no meio aquático (qualidade da água e fauna aquática) e meio socioeconômico (CONSPLAN, 1990). Como resultado, o projeto traria poucos impactos negativos e mais possibilidades de desenvolvimento. Até o ano de 2010, o projeto não havia sido executado, encontrando-se estagnado desde sua concepção.

A população do entorno da barragem é constituída, em sua maioria, por moradores, alguns comerciantes que exploram o turismo local, e com algumas casas de veraneio. No entorno da Barragem Piracuruca moram 90 famílias, que convivem com a barragem em seu dia a dia, dispondo de plantios de hortaliças e de lavouras de subsistência, da criação de animais de pequeno porte (Figura 4) e de atividades de pesca. Uma grande maioria da população ribeirinha que sobrevive da pesca profissional é associada à Colônia de Pescadores Z-05 do município de Piracuruca.

Outra característica interessante, sobre a ocupação em volta da área da barragem, é a existência de aproximadamente 50 casas de veraneio (Figura 5). Os proprietários se fazem mais presentes nos períodos propícios ao fluxo turístico, tais como, férias e finais de semana prolongados por feriados. As casas se aglomeram mais próximas do principal balneário da Barragem 


\section{Piracuruca.}

Figura 4: Agricultura de subsistência e criação de animais de pequeno porte das famílias do entorno da Barragem Piracuruca.
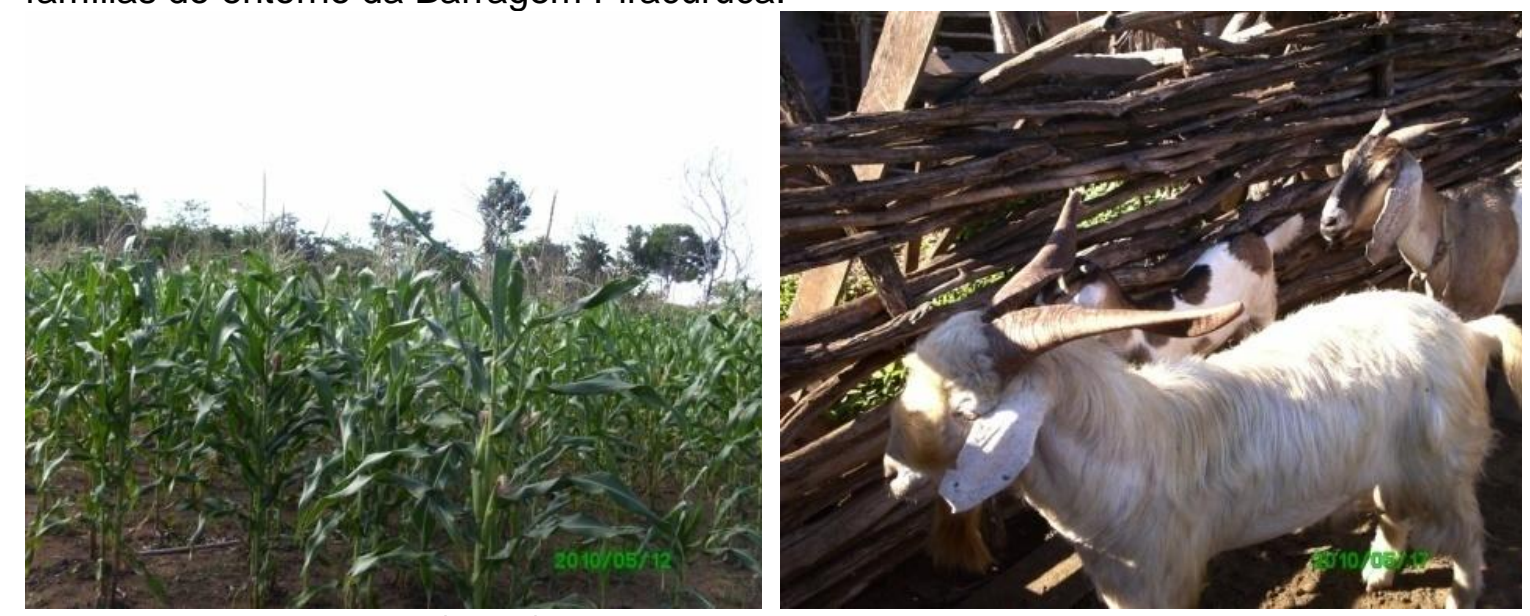

Fonte: Roberta Ferreira (2010).

Segundo Macedo (2002, p. 181), este tipo “[...] de ocupação também urbana, é destinada fundamentalmente para o veraneio, para o turismo de férias de amplos continentes sociais, abarcando os segmentos mais ricos da população brasileira (da crescente classe média às elites)". Trata-se do fenômeno turístico da segunda residência, relacionada, principalmente, à costa marítima, lagos e cursos de rios.

Figura 5: Casas de veraneio.
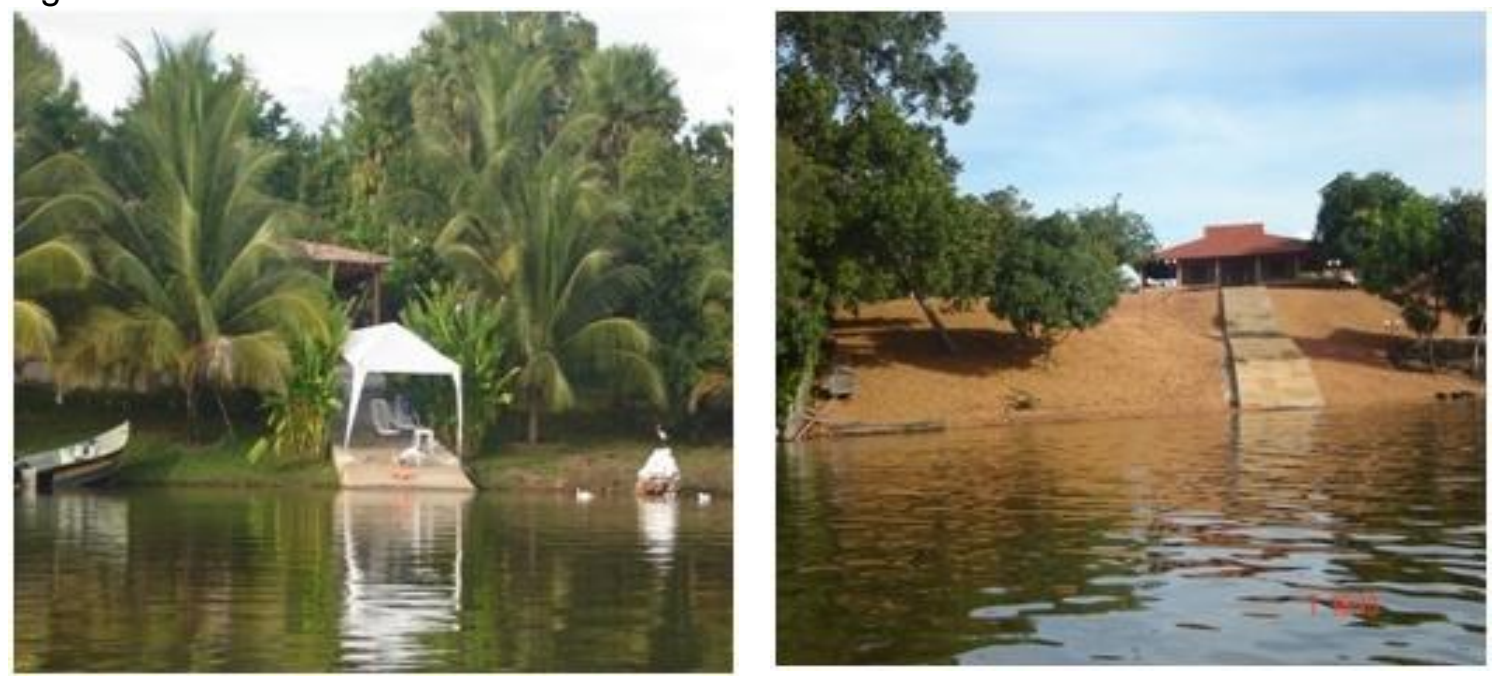

Fonte: Roberta Ferreira (2010). 
Os bares situados no entorno da barragem (cerca de 10 estabelecimentos) são de características simples, embora a Empresa de Gestão de Recursos do Piauí (EMGERPI) esteja construindo um balneário (Figura 6), com infraestrutura adequada para receber os visitantes que buscam momentos de lazer e descontração.

Figura 6: Bar e Balneário da EMGERPI, em construção, próximos a barragem.
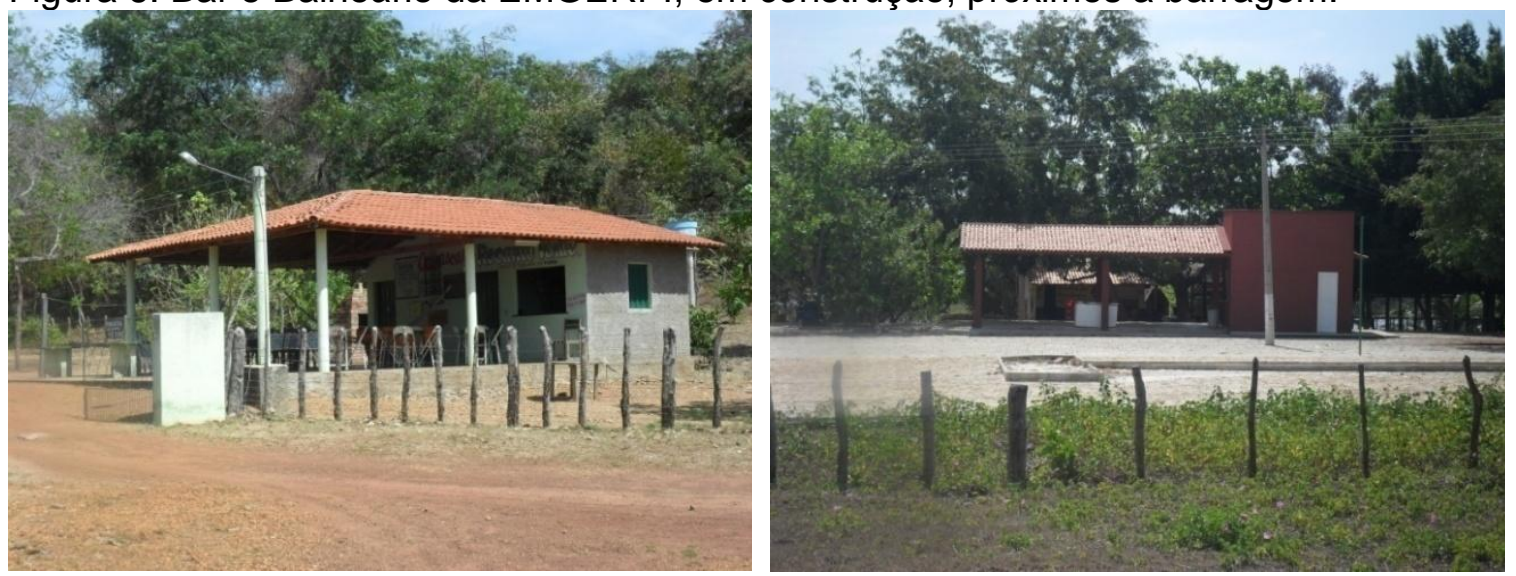

Fonte: Roberta Ferreira (2010).

Possibilidades, limitações e impactos das atividades de lazer e turismo na Barragem Piracuruca

Espaço e lazer são dois termos diferentes, mas que aparentam ser familiares. Espaço, enquanto unidade geométrica (área ou volume) é uma quantidade mensurável e precisa, em outras palavras significa lugar (room) (TUAN, 1980). Já o lazer pode ser compreendido como uma ou mais atividades que a pessoa pratica, visando sua fruição, descanso, recreio, ou mesmo para ampliar seus conhecimentos, onde não estão envolvidos obrigações das atividades do trabalho (DUMAZEDIER, 1973).

Turismo, espaço e lazer são dimensões contíguas que se justapõem, proporcionando alternativas de alívio do estresse do cotidiano. Nessa perspectiva, salienta-se o uso das barragens para o lazer e o turismo como uma excelente opção.

Ferreira (2007, p. 167) define barragem como "estrutura construída num 
vale e que o fecha transversalmente, proporcionando um represamento de água", significando o mesmo que represa. A criação das barragens tem gerado conflitos, em virtude das formas de desapropriação das famílias locais para a sua instalação. Temas sociais, envolvendo esses problemas, requerem a participação de movimentos sociais para reivindicação dos direitos das pessoas atingidas por suas instalações.

As barragens também propiciam benefícios com sua construção, tais como, o controle de enchentes, o abastecimento d'água, a irrigação, a geração de energia, a navegação, a pesca e a recreação. Se bem planejadas, podem promover o desenvolvimento sustentável ambiental, além do desenvolvimento econômico e social das famílias autóctones.

Dessa maneira, o conhecimento da fonte hídrica é o principal passo para a gestão eficaz das águas. A utilização de barragens e o contexto que as envolvem têm despertado a atenção de inúmeros setores, como a indústria do turismo, o setor público e os turistas. Na visão de Leme (2007, p. 74),

com a introdução de um grande volume de água para a construção de uma represa, é alterado não somente o clima, a vegetação, a ocupação da área, mas também a estética e as possibilidades de uso do local, como para a pesca e prática de esportes náuticos. Este fato acaba por gerar uma nova perspectiva sobre o território, a de sua apropriação para 0 lazer, moldando também novos lugares.

Leal e Guimarães (2009, p. 105) ressaltam os impactos negativos que uma atividade de lazer pode trazer para uma fonte aquífera, e as principais medidas que podem ser tomadas para evitar o agravamento desse quadro. Segundo os autores:

Diante de situações críticas que atingem muitas localidades, provocando a escassez relativa da água, e da necessidade imperiosa de se tentar reverter esse quadro de intensa degradação ambiental, enfatiza-se a urgência de realização de programas e projetos de Educação Ambiental e de estudos a partir da bacia hidrográfica local, valorizando os trabalhos de campo, como uma estratégia para compreender os processos atuantes e buscar os caminhos para reduzir os impactos das ações antrópicas ou dos desastres naturais. 
Por ser o Brasil um país rico em belezas naturais e recursos hídricos, alguns reservatórios d'água, construídos para a geração de energia elétrica, passaram a ser buscados como alternativa de lazer e turismo (Quadro 1). Segundo Almeida, Viana e Alves (2007, p. 3) "os corpos d'água oferecem várias alternativas de turismo e recreação, por meio de atividades como esportes aquáticos, pesca e navegação esportiva". Os autores referem-se também, as atividades realizadas nas margens dos reservatórios, destacando casas de veraneio, acampamento, trekking, pesca, piquenique, observação de pássaros e banho de sol. Ressaltam, ainda que tais atividades estão relacionadas e dependentes da qualidade da água e das dimensões do espelho d'água.

Quadro 1: Principais reservatórios nacionais para aproveitamento turístico.

\begin{tabular}{|c|c|c|c|c|c|}
\hline Reservatório & $\begin{array}{c}\text { Área } \\
\text { inundada } \\
\left(\mathrm{km}^{2}\right)\end{array}$ & $\begin{array}{l}\text { Perímetro } \\
(\mathbf{k m})\end{array}$ & Rio & UF & Município \\
\hline Sobradinho & 4.214 & 1.352 & $\begin{array}{c}\text { São } \\
\text { Francisco }\end{array}$ & BA & $\begin{array}{c}\text { Casa Nova, } \\
\text { Juazeiro }\end{array}$ \\
\hline Tucuruí & 2.430 & $\begin{array}{c}8.396 \\
\text { (incluindo } \\
\text { todas as ilhas) }\end{array}$ & Tocantins & PA & Tucuruí \\
\hline Serra da Mesa & 1.784 & 3898 & Tocantins & $\mathrm{GO}$ & Minaçu \\
\hline Furnas & 1.442 & 3.500 & Grande & $\begin{array}{l}\text { SP, } \\
\text { MG }\end{array}$ & $\begin{array}{c}\text { São João da Barra, } \\
\text { Alpinópolis }\end{array}$ \\
\hline Itaipú & 1.350 & 1.400 & Paraná & PR & Foz do Iguaçu \\
\hline Três Marias & 1.009 & 2.297 & $\begin{array}{c}\text { São } \\
\text { Francisco }\end{array}$ & MG & Três Marias \\
\hline $\begin{array}{l}\text { Lajeado (Luís } \\
\text { Eduardo } \\
\text { Magalhães) }\end{array}$ & 626 & 1.164 & Tocantins & TO & Lajeado \\
\hline${ }^{*}$ Promissão & 530 & 1.423 & Tietê & SP & Promissão \\
\hline Xingó & 60 & 65 & $\begin{array}{c}\text { São } \\
\text { Francisco }\end{array}$ & $\begin{array}{l}\mathrm{AL}, \\
\mathrm{SE}\end{array}$ & $\begin{array}{c}\text { Piranhas, } \\
\text { Canindé de São } \\
\text { Francisco }\end{array}$ \\
\hline Caconde & 31 & 269 & Pardo & SP & $\begin{array}{c}\text { São José do Rio } \\
\text { Pardo }\end{array}$ \\
\hline Paranoá & 40 & 80 & Paranoá & DF & Brasília \\
\hline
\end{tabular}

Fonte: (BRASIL, 2005, p. 22) adaptado para incluir o Reservatório de *Promissão.

Em ambos os reservatórios, os tipos de turismo desenvolvidos são sempre baseados nos recursos ambientais, em especial a água: ecoturismo, turismo de esportes, turismo de pesca, turismo náutico, turismo de aventura, 
turismo de sol e praia, com atividades de lazer relacionadas ao banho de sol e em praias fluviais, canyons, cachoeiras e riachos, pesca, passeio de barcos e chalanas, caminhadas em trilhas ecológicas e mirantes, canoagem, iatismo, banana-boat, jetski, rafting, canyoning, trekking com tirolesa, mountain bike e motocross, boiacross, wakeboard e rappel, com infraestrutura nos terminais turísticos, praias artificiais, clubes e bases náuticas, bares e restaurantes (BRASIL, 2005). De acordo com Meneguel (2010), as praias fluviais formadas pelos reservatórios são procuradas por turistas durante o ano todo.

Com relação ao turismo de lazer em lagos e reservatórios, Pertille e Lanzer (2006, p. 6) afirmam que é possível observar

\begin{abstract}
um crescimento vertiginoso, em especial nos reservatórios de hidrelétricas citando como exemplo os sete terminais turísticos no lago da Itaipu Binacional, localizados nos municípios de Foz do Iguaçu, Santa Terezinha de Itaipu, São Miguel do Iguaçu, Itaipulândia, Missal, Marechal Cândido Rondon e Santa Helena.
\end{abstract}

Muller (1995) se reportando aos estudos elaborados pela Eletrobras em 1977, sobre 89 grandes represas, diz que: dos 14 possíveis usos das águas represadas, os cinco primeiros têm a ver com a recreação, tais como: pesca amadora, acampamentos, caça, esportes aquáticos e turismo.

No caso da Barragem Piracuruca, situada no município de mesmo nome, não é diferente. A mesma é procurada em boa parte do ano, possibilitando realizar atividades de lazer e turismo em contato com o meio natural, destacando-se banhos aquáticos e de sol, pesca, mirante, campeonato de jetski, show acústico (Figura 7).

Outras atividades também podem ser executadas, desde que haja uma logística de infraestrutura, tais como: iatismo, banana-boat, uso recreativo de jetski, mountain bike e motocross, wakeboard (esporte aquático praticado com uma prancha tipo snowboard, puxado por uma lancha), competições esportivas, camping, observação de animais, em especial de pássaros, passeios de barcos e de canoas, além de caminhadas em trilhas ecológicas. É possível, ainda, a realização de apresentações artísticas e culturais, de atividades esportivas (natação recreacional, hidrocapoeira, acquavolley e o 
handebol aquático), de encontros da terceira idade e de confraternizações, podendo desempenhar um ótimo papel no desenvolvimento do turismo e de atividades de lazer. Não se pode esquecer, também, da possibilidade de desenvolvimento do ecoturismo, turismo de esportes, turismo de pesca, turismo náutico, turismo de aventura, turismo de sol e praia.

Figura 7: Banho de sol e no lago, bate papo, descontração e lazer na Barragem Piracuruca.
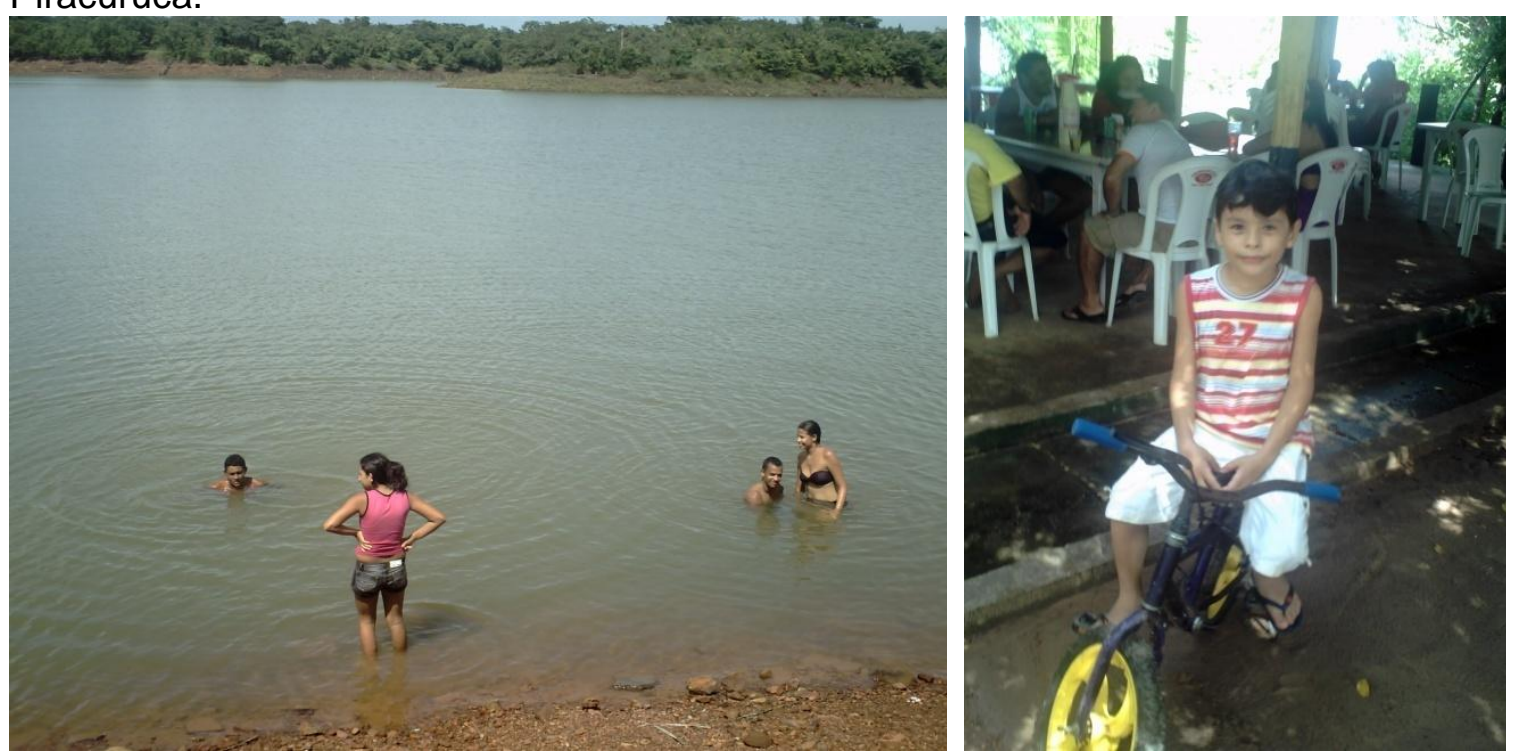

Foto: Roberta Ferreira (2010).

A barragem de Piracuruca está situada em um município que se destaca, turisticamente, por seu conjunto arquitetônico, pelas diversas manifestações culturais existentes, pelos atrativos naturais da região, como o Parque Nacional de Sete Cidades e pela própria potencialidade de lazer e recreação que propicia. Dessa forma, apresenta-se ideal para o contato com o meio natural, favorecendo atividades de aventura, sossego, paz e lazer, sendo possível desenvolver, em seu entorno, o turismo rural, turismo cultural, turismo social, e turismo de estudos e intercâmbio, o que pode contribuir para a educação cultural e ambiental, fazendo com que o turismo possa ser uma alternativa econômica para os moradores do local.

A maior movimentação na barragem (Figura 8) ocorre nos períodos de fins de semana prolongados por feriados, nos meses de junho e julho e nas festividades de final de ano, que têm início em dezembro, se estendendo até o 
final de fevereiro ou início de março, com os festejos do Carnaval. Percebe-se, então, que de alguma forma os visitantes buscam na barragem opções de lazer, praticamente o ano inteiro.

Figura 8: Movimentação turística na Barragem Piracuruca.

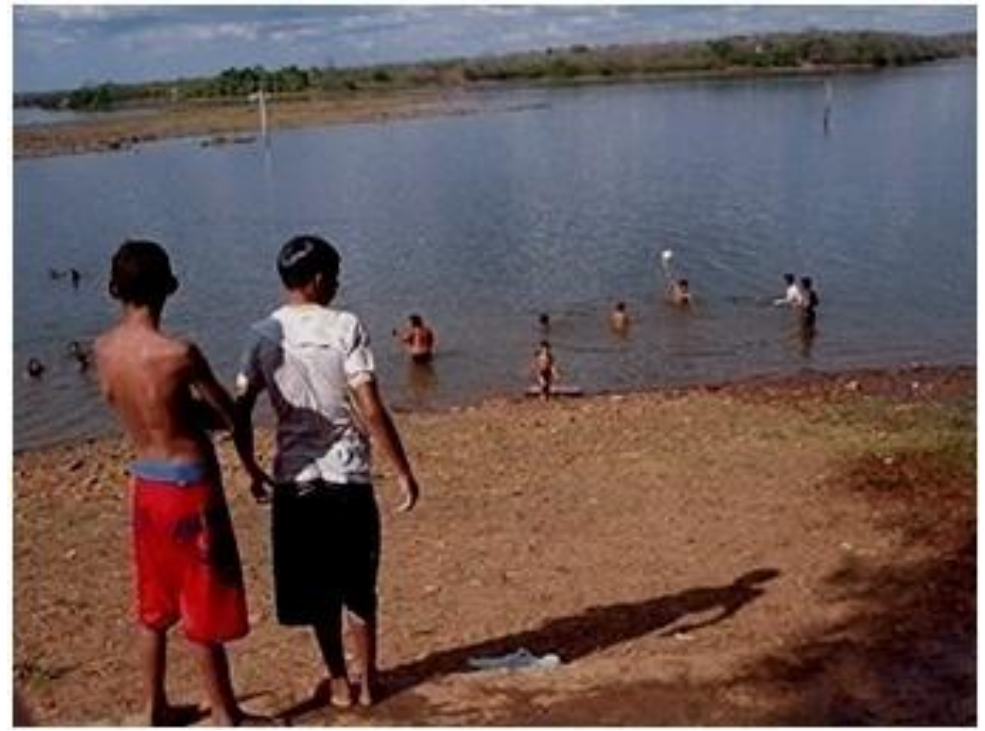

Fonte: Roberta Ferreira (2010).

Foram realizadas três etapas do Circuito Piauiense de Jet-Ski nas águas represadas da barragem, sendo a primeira no ano de 2007, a segunda em 2008 e a terceira em 2009, o que elevou o contingente de visitantes no período de apresentação dos competidores (Figura 9), com a participação de várias equipes de ambos os sexos. Evento realizado pela iniciativa privada, contando com a parceria da iniciativa pública (Prefeitura Municipal). Nos anos de 2010 e 2011 não foram realizadas competições esportivas na barragem, devido à realização de reparos em sua parede de contenção das águas.

Fatores limitantes são perceptíveis ao desenvolvimento de atividades de lazer e turismo na barragem e no seu entorno. Como entraves mais urgentes destacam-se: falta de compromisso, por parte do setor público na implementação de infraestrutura e estruturação de políticas públicas, participação da iniciativa privada no envolvimento com a atividade turística, planejamento turístico participativo de médio e longo prazo, envolvendo a comunidade na pauta de discussão, referente ao turismo, sensibilidade e educação ambiental. 
Figura 9: Prática esportiva na Barragem Piracuruca.

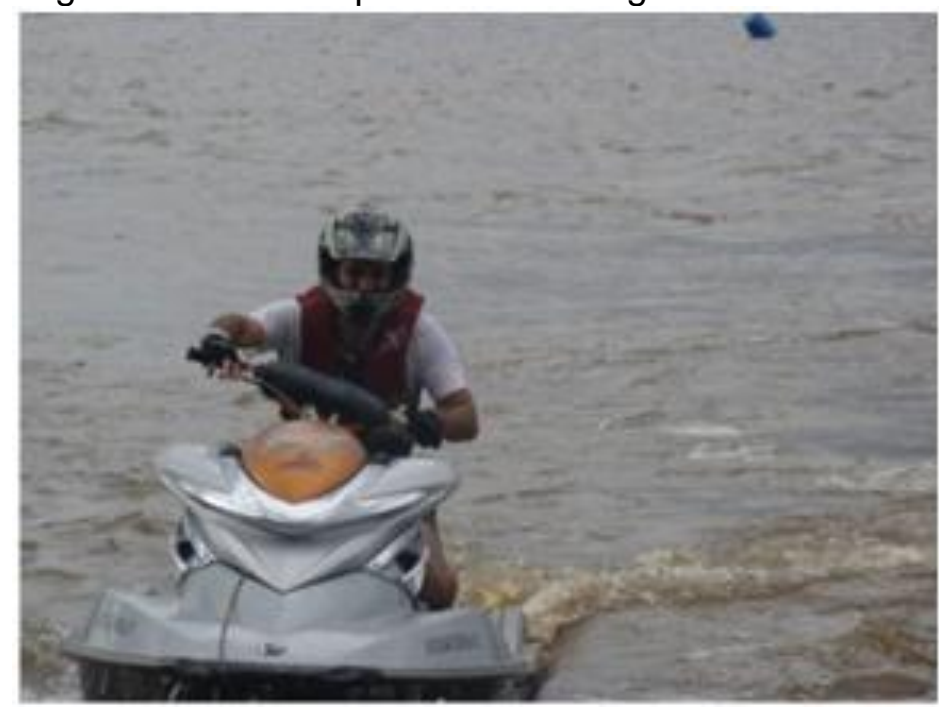

Fonte: Roberta Ferreira (2009).

Devido à falta de controle e planejamento da atividade turística no entorno da Barragem Piracuruca, não se dispõe de uma quantidade real de visitantes, por mês, na barragem. Mas, respaldando-se na quantidade de veículos estacionados no local, foi possível mensurar a quantidade de, aproximadamente, 600 visitantes por mês, incluindo (alta/baixa) temporada.

Embora a ocupação de áreas naturais, com foco no lazer e no turismo, favoreça o bem-estar pessoal e a qualidade de vida dos seus ocupantes, podendo gerar riquezas para o município como um todo, pode ocorrer, também, impactos negativos, tanto econômicos, como socioculturais e ambientais, em todos os recursos naturais (terra, água, flora e fauna). Entre estes, destacam-se a redução do espaço natural livre e a poluição de aquíferos, em decorrência da deposição de lixo e de esgoto. Isso ocorre, em grande parte, devido à falta de planejamento da atividade turística e de um programa de educação ambiental. Embora, como afirmam Brito et al., (2002, p. 355), "todos os impactos identificados podem ser mitigados ou potencializados, conforme o caso".

A paisagem no entorno da Barragem mudou, devido ao uso do solo e a cobertura vegetal. Anterior à construção da barragem situavam-se poucas casas de médio a grande porte no entorno do rio Piracuruca (PIAUÍ, 1987). 
Com o passar dos anos as casas de veraneio se expandiram de maneira significativa, após a construção da barragem, prevendo-se uma densidade demográfica alta em pouco tempo, impermeabilizando o solo, removendo porções de terra e contribuindo para a redução da mata ciliar (desmatamento), que tem sido provocada com intensidade. Tal ação provoca o assoreamento do rio Piracuruca, causando riscos de contaminação do lençol freático, devido à construção de fossas sépticas, podendo causar danos ao meio ambiente.

Com a propagação de casas de veraneio, reduziram-se os plantios de lavouras de subsistência e a criação de animais de pequeno porte, próximos à Barragem. A quantidade de casas de veraneio no entorno da barragem tem prosperado a intensa especulação imobiliária da área, promovida, sobretudo, pelas oportunidades de lazer encontradas na região, e pela proximidade com as águas.

Migliorini et al. (2010, p. 137), estudando a necessidade de se planejar o uso turístico do lago do reservatório da usina Salto Osório no Paraná, também diagnosticaram que "[...] muitas residências existentes às margens do lago foram construídas encostadas no reservatório, o que significa que os proprietários não estavam preocupados em respeitar e preservar o meio ambiente, mas sim em usufruir ao máximo deste local".

Foi observada a ocorrência de alguns problemas ambientais, que podem culminar em uma possível poluição das águas da barragem, pelo lançamento de dejetos no reservatório por moradores do entorno, veranistas, visitantes e proprietários de bares e restaurantes (Figura 10). Não havendo saneamento básico, o descarte e a falta de tratamento do esgoto e dos resíduos sólidos, que se acumulam às margens da barragem, podem contribuir para a propagação de vermes e doenças para a saúde da população que usa as águas da barragem, seja para o lazer ou para consumo próprio (OMT, 2003). O acúmulo de lixo traz um aspecto incompatível com a atividade turística, pois expressa a carência de uma conscientização ambiental por parte das pessoas que usufruem desse bem público e da gestão municipal. 
Figura 10: Acúmulo de lixo e lançamento de dejetos às margens e no reservatório da barragem.
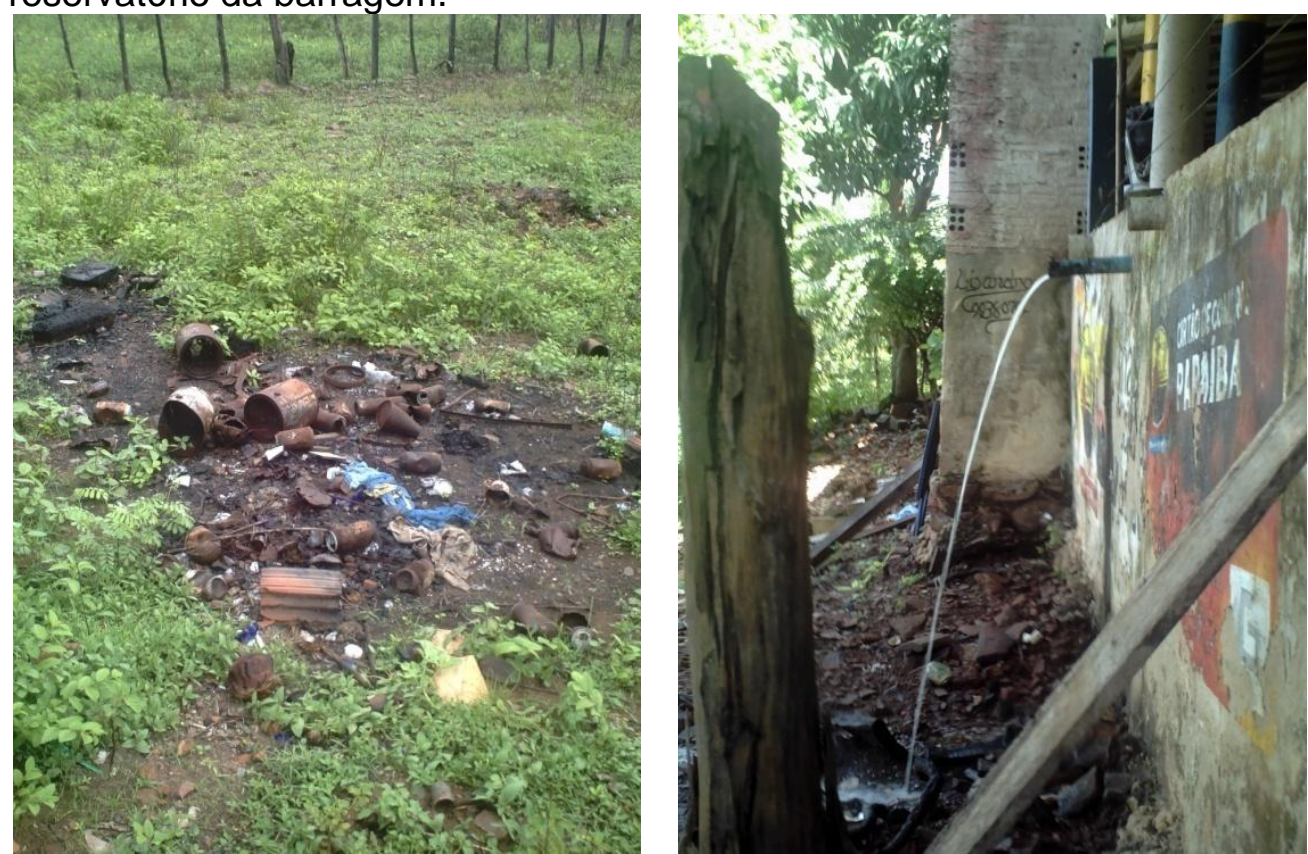

Fonte: Roberta Ferreira (2010).

O uso de equipamentos náuticos para a prática de esportes, como os barcos a motor e os jetski (pouco usado, na maioria das vezes apenas nas etapas estaduais, que acontecem uma vez ao ano), lançam óleos e graxas no lago.

\section{Considerações finais}

O turismo é uma atividade que, de certa forma, se apropria de lugares e espaços, criando e recriando lugares com possibilidades de lazer e turismo. A prática de atividades de lazer em qualquer localidade, além de dinamizar o turismo regional, mostra-se necessária para o bem-estar das pessoas, sejam turistas ou moradores, que dependem diretamente do atrativo turístico.

A atividade turística atuante no meio ambiente ganhou vigor com a valorização das paisagens naturais e com o ambientalismo contemporâneo, contribuindo para que a Barragem Piracuruca seja uma possibilidade para o incremento econômico. Assim, a barragem, tendo como atrativo suas belezas naturais, dispõe de boas condições para desenvolver o turismo local, o que 
deve ser feito com prudência e diligência por parte da administração pública e pelos próprios visitantes.

No entanto, é preciso uma nova visão de preservação do patrimônio, para que o turismo seja uma das principais ferramentas de desenvolvimento sustentável, que deve cuidar, primordialmente, da qualidade dos recursos ambientais, que são de usufruto de todos. Destaca-se que o patrimônio ambiental é a base para o turismo, possibilitando, também, o desenvolvimento econômico das regiões que contemplam barragens, bem como, oportunizando atrativos turísticos de qualidade à população.

Várias atividades podem ser realizadas na Barragem Piracuruca, desempenhando assim, um ótimo papel no desenvolvimento do turismo e de atividades de lazer na localidade, desde que haja uma logística de estruturação e de infraestrutura.

A barragem sofre constantemente com o problema do lixo e despejo indevido de esgoto em suas águas, o que aumenta os riscos à saúde da população e dos visitantes. Além disso, notou-se que a população autóctone mais carente está vivenciando um processo de "marginalização territorial", em que está sendo afastada do entorno da barragem, para dar lugar a construções mais luxuosas. Isto demonstra a especulação imobiliária em toda a extensão da construção, o que não deixa de ser limitação ao desenvolvimento do turismo, assim como a falta de infraestrutura adequada. Nesse caso, a administração pública deve atender a todos que têm a Barragem Piracuruca como um espaço de lazer ou de sustento, sempre levando em consideração que a economia local depende, intrinsecamente, da efetiva gestão desse bem público, aliada à preservação ambiental.

Os danos ambientais provocados pelas atividades de lazer desenvolvidas na Barragem Piracuruca, detectados pela presente pesquisa, ainda não são alarmantes, mas podem se tornar drásticos, em um futuro bem próximo, caso a administração pública, com apoio da sociedade civil, não voltem sua atenção para a questão. Também, é preocupante a falta de saneamento básico no entorno da barragem, assim como o desmatamento, para a construção de casas e para o cultivo da agricultura de subsistência. 
A atividade turística, associada a outros usos dos recursos hídricos na maioria dos reservatórios no Brasil, ainda ocorre de forma desordenada e despreocupada, provocando impactos ambientais negativos. Verificou-se que a Barragem Piracuruca é compatível com a inserção de práticas de lazer e turismo, mas necessita, além de tudo, de uma boa administração em prol da preservação da qualidade ambiental.

\section{Referências}

ALMEIDA, Roberto Alves; VIANA, Augusto Nelson Carvalho; ALVES, Ana Sofia Viana. Impacto do deplecionamento de reservatórios de regularização no setor de turismo em municípios lindeiros: o caso do reservatório de furnas. In: SIMPÓSIO BRASILEIRO DE RECURSOS HÍDRICOS, 17., 2007, São Paulo, Anais... São Paulo: ABRH, 2007. P.1-11.

BARRETO, Margarita. Manual de iniciação ao estudo do turismo. 14. ed. Campinas, SP: Editora Papirus, 2005.

BRITO, Elizabeth Rodrigues; SILVA, Elias; MARTINS, Sebastião Venâncio; RIBEIRO, Guido Assunção. Perfil ambiental do empreendimento denominado de "praias fluviais", estado do Tocantins. Revista Árvore, Viçosa-MG, v. 26, n. 3, 2002. p. 349-355.

BRASIL. Ministério do Turismo. Segmentação do turismo: marcos conceituais. Coordenação geral de segmentação. Brasília: Ministério do Turismo, 2006a

. Companhia de Desenvolvimento dos Vales do São Francisco e do Parnaíba - CODEVASF. Plano de Ação para o Desenvolvimento Integrado da Bacia do Parnaíba, PLANAP: Atlas da Bacia do Parnaíba - Brasília, DF: TDA Desenho \& Arte Ltda., 2006b.

- Ministério do Meio Ambiente. Agência Nacional de águas - ANA. O turismo e o lazer e sua interface com o setor de recursos hídricos. Brasília: ANA, 2005 (Caderno de Recursos Hídricos).

CNRH. Resolução № 32, de15 de outubro de 2003. Dispõe sobre Divisão Hidrográfica Nacional em regiões hidrográficas, com a finalidade de orientar, fundamentar e implementar o Plano Nacional de Recursos Hídricos. Disponível em:<http://www.cnrh-srh.gov.br>. Acesso em: 20 ago. 2010. 
BRUHNS, Heloisa Turini. A ideia de natureza como fronteira. In: PAESLUCHIARI, Maria Teresa; BRUHNS, Heloisa Turini.; SERRANO, Celia. (orgs.).

Patrimônio, natureza e cultura. Campinas, SP: Papirus, 2007. p. 79-102.

CONSPLAN. Projeto de irrigação Piracuruca: Estudo de Impacto Ambiental. Teresina, PI: Consultoria e Planejamento LTDA, 1990.

COOPER, Chris; FLETCHER, John; FYALL, Alan. Turismo: princípios e prática. 3. ed. Porto Alegre: Bookman, 2007.

CORIOLANO, Luzia Neide Menezes Teixeira; VASCONCELOS, Fabio Perdigão. Sustentabilidade e insustentabilidades do turismo litorâneo. Revista da Gestão Costeira Integrada, n.8, v. 2, 2008, p. 11-23.

CORIOLANO, Luzia Neide Menezes Teixeira; VASCONCELOS, Fabio Perdigão. $O$ turismo e a relação sociedade - natureza: realidades, conflitos e resistências. Fortaleza: EdUECE, 2007.

DIAS, Reinaldo. Introdução ao turismo. São Paulo: Atlas, 2005.

DIEGUES, Antonio Carlos. Etnoconservação da natureza: enfoques alternativos. IN: DIEGUES, Antonio Carlos. (org.). Etnoconservação: novos rumos para a proteção da natureza nos trópicos. São Paulo: Hucitec, 2000. p. $1-46$.

DUMAZEDIER, Joffre. Lazer e cultura popular. São Paulo: Perspectiva, 1973.

FERREIRA, Roberta Celestino. 01 foto. Digital color, 2009.

FERREIRA, Roberta Celestino. 7 fotos. Digital color, 2010.

FERREIRA, Aurélio Buarque de Holanda. Novo dicionário da língua portuguesa. 6. ed. rev. e amp. Curitiba: Editora Positivo, 2007.

LEAL, Antonio Cezar; GUIMARÃES, Eliana Maria Alves. Gestão das águas e educação ambiental. In: SEABRA, Giovanni. (org.). Educação ambiental. João Pessoa: Editora Universitária da UFPB, 2009. p, 93-106.

LEME, Fernanda Beraldo Maciel. As represas como lugares turísticos: novas significações e valorizações de uma paisagem sem memória. CONTUR Revista de Cultura e Turismo. Ano 1, n. 1, 2007.

MACEDO, Silvio Soares. Paisagem turismo e litoral. In: YÁZIGI, Eduardo. Turismo e paisagem. São Paulo: Contexto, 2002. p. 181-213.

MACHADO, Iran de Brito. Piracuruca: iniciando Geografia e História. Piracuruca: PI, 2008. 
MENEGUEL, Cinthia Rolim de. Turismo fluvial de base comunitária como alternativa econômica sustentável aos municípios do alto rio Paraná. 2010, 196 f. Dissertação (Mestrado em Análise Geoambiental) - Universidade de Guarulhos - UNG, 2010.

MIGLIORINI, Sonia Mar dos Santos; SOUSA, Lucileyde Feitosa; BIESEK, Ana Solange; RITTER, Carlos. A necessidade de se planejar o uso turístico do lago do reservatório da usina Salto Osório - Paraná: atividades turísticas desenvolvidas no local e os consequentes impactos ambientais. Revista Geografar, Curitiba, v.5, n.2, jul./dez. 2010. p.115-142.

MULLER, Arnaldo Carlos. Lazer, desenvolvimento regional: como pode nascer e se desenvolver uma ideia. In: MULLER, Arnaldo Carlos; COSTA, Lamartine Pereira. Lazer e desenvolvimento regional. Santa Cruz do Sul: EDUNISC, 2002. p. 9-40.

MULLER, Arnaldo Carlos. Hidrelétricas, meio ambiente e desenvolvimento. São Paulo: Markon Books, 1995.

OMT - Organização Mundial do Turismo. Guia de desenvolvimento do turismo sustentável. Trad. Sandra Netz. Porto Alegre: Bookman, 2003.

ONU - Organização das Nações Unidas. Declaração Universal dos Direitos da Água. Organização das Nações Unidas, 1992.

PERTILLE, lara; LANZER, Rosane. Turismo em reservatórios de hidrelétricas: uma reflexão sobre o múltiplo uso e os possíveis impactos ambientais. In: SEMINÁRIO DE PESQUISA EM TURISMO DO MERCOSUL, 4. 2006. Caxias do Sul. Anais... Caxias do Sul: Universidade de Caxias do Sul, 2006. p. 1-11.

PIAUÍ. Barragem de Piracuruca - Piauí: Relatório de impacto no meio ambiente. Piracuruca, Pl; Serviços Integrados de Assessoria e Consultoria LTDA: FUNDAÇÃO CEPRO. Janeiro de 1987.

Ficha técnica: Barragem de Piracuruca. Piracuruca, PI: Companhia de Desenvolvimento do Piauí - COMDEPI, 1997.

POLO, Rodrigo Balsalobre. Turismo fluvial no Reservatório de Promissão (SP): estudo de caso da hospitalidade e do turismo receptivo na Prainha da Pedra Branca. 2008, 117 f. Dissertação (Mestrado em Hospitalidade). Universidade Anhembi Morumbi, São Paulo, 2008.

QUEIROZ, Odaléia Telles Marcondes Machado. A paisagem como atrativo turístico no interior de São Paulo. In: SEABRA, Giovanni. (org.). Educação ambiental. João Pessoa: Editora Universitária da UFPB, 2009.p. 171-184. 
SEABRA, Giovanni. Educação ambiental na sociedade do consumo e riscos. In: SEABRA, Giovanni. (org.). Educação ambiental. João Pessoa: Editora Universitária da UFPB, 2009. p. 11-14.

SILVA FILHO, Jeremias Pereira. Avaliação ambiental da represa de Piracuruca (Piracuruca - Piauí), com ênfase nas características físicas e químicas da água e na comunidade zooplanctônica. 2002,185 f. Tese (Doutorado em Ciências da Engenharia Ambiental) Universidade de São Paulo, São Carlos, 2002.

TUAN, Yi-Fu. Topofilia: um estudo da percepção, atitudes e valores do meio ambiente. São Paulo: DIFEL, 1980. 